\title{
PENINGKATAN HASIL BELAJAR MATEMATIKA MELALUI PEMBELAJARAN METODE DISCOVERY LEARNING
}

\author{
Nurfaida Tasni * \\ ABSTRACT
}

This research is Classroom Action Research aimed at improving students mathematics achievement of Class VIII A Students of SMP Negeri 10 Bulukumba through the implementation of discovery learning method. The subject of the research were Class VIII $I_{A}$ Students of SMP Negeri 4 Bulukumba. The study was conducted within two cycles. The first cycles was conducted for 4 lessons and the second cycles for 5 lessons. Data were gathered using mathematics achievements test in each final of cycle according the matherial that is taught. Data were then analyzed by employing both qualitative and quantitative analyses. From descriptive analysis show that: (1) Within the first cycle, the students average score reached in the achievement test was 56,83; which was categorized as being in moderate level. Within the second cycle with the correction based on the reflection from the first cycle, there was an improvement of the mathematics achievement of student become 79,98; which was categorized as being in high level. (2) Students were more active in the process of teaching and learning. Beside happened improving mathematics achievement in each cycle caused: (1) The students more the more active forward in front of the class to doing question, improved from $16,9 \%$ become $49 \%$. (2) The students were the more ask at the implementation happens improved from $15 \%$ become $23 \%$. (3) The students are doing their homework improved from $57,5 \%$ become $89,5 \%$. According the analysis data above, it could be concluded that the mathematics achievement of Class $V I I_{A}$ Students of SMP Negeri 10 Bulukumba improved after the implementation of discovery learning method.

Keywords: Learning Mathematics, Discovery Learning Method

*) Jurusan Pendidikan Matematika STKIP-YPUP

E-mail: Nurfaidatasni@rocketmail.com. 


\section{PENDAHULUAN}

Matematika sebagai salah satu mata pelajaran inti di sekolah memegang peranan penting dalam penguasaan IPTEK. Hal ini disebabkan matematika merupakan sarana berpikir logis, sistematis, dan kritis. Berdasarkan uraian tersebut, bahwa matematika itu sangat penting dan keberadaannya sangat diperlukan, sehingga upaya selanjutnya adalah bagaimana agar matematika itu dapat dipelajari, diketahui, dan dipahami sampai akhirnya dapat diterapkan oleh semua orang dalam kehidupan sehari-hari dalam bentuk yang paling sederhana sekalipun.

Suatu kecenderungan yang sering terjadi dimana banyak keluhan tentang matematika, bahwa matematika itu membosankan, tidak menarik, dan bahkan penuh misteri. Hal ini disebabkan karena pelajaran matematika dirasakan sukar dan tidak tampak kaitannya dengan kehidupan sehari-hari yang akibatnya pemahaman siswa terhadap konsep matematika sangatlah minim.

Penguasaan materi dan pemilihan metode atau teknik pembelajaran serta penguasaan keterampilan dasar mengajar merupakan suatu alternatif dalam upaya meningkatkan mutu pengajaran dan hasil belajar matematika siswa. Berhasil tidaknya seseorang siswa dalam pelajaran matematika dapat dipengaruhi oleh beberapa faktor, baik dari dalam maupun dari luar siswa. Salah satu diantaranya adalah dengan memberikan metode yang dapat memberikan kontribusi yang positif terhadap hasil belajar matematika.

Dari kenyataan tersebut, penulis memilih metode discovery learning yang bertujuan untuk meningkatkan hasil belajar siswa disebabkan 
metode ini merupakan suatu cara untuk mengembangkan cara belajar siswa aktif. Dengan menemukan sendiri, menyelidiki sendiri, maka hasil yang diperoleh akan setia dan tahan lama dalam ingatan, tak mudah dilupakan anak. Lagipula pengertian yang ditemukan sendiri merupakan pengertian yang betul-betul dikuasai dan mudah digunakan atau ditransfer dalam situasi lain. Dengan metode discovery learning ini juga, anak belajar berpikir analisis dan mencoba memecahkan masalah yang dihadapi sendiri; kebiasaan ini akan ditransfer dalam kehidupan masyarakat.

\section{Metode Discovery Learning}

Salah satu metode mengajar yang akhir-akhir ini banyak digunakan di sekolah-sekolah yang sudah maju adalah "metode penemuan". Hal ini disebabkan karena metode penemuan itu:

a. Merupakan suatu cara untuk mengembangkan cara belajar siswa aktif.

b. Dengan menemukan sendiri, menyelidiki sendiri, maka hasil yang diperoleh akan setia dan tahan lama dalam ingatan, tak mudah dilupakan anak.

c. Pengertian yang ditemukan sendiri merupakan pengertian yang betulbetul dikuasai dan mudah digunakan atau ditransfer dalam situasi lain.

d. Dengan menggunakan strategi penemuan anak belajar menguasai salah satu metode ilmiah yang akan dapat dikembangkan sendiri.

e. Dengan metode penemuan ini juga, anak belajar berpikir analisis dan mencoba memecahkan masalah yang dihadapi sendiri; kebiasaan ini 
akan ditransfer dalam kehidupan masyarakat. Dengan demikian diharapkan metode penemuan ini lebih dikenal dan digunakan di dalam berbagai kesempatan proses belajar mengajar yang memungkinkan. Menurut Richard Scuhman (Suryosubroto, 1997:199) langkah-langkah metode penemuan adalah sebagai berikut:

1. Identifikasi kebutuhan siswa.

2. Seleksi pendahuluan terhadap prinsip-prinsip, pengertian konsep dan generalisasi yang akan dipelajari.

3. Seleksi bahan, dan problema/tugas-tugas.

4. Membantu memperjelas.

a. Tugas/problema yang akan dipelajari.

b. Peranan masing-masing siswa.

5. Mempersiapkan setting kelas dan alat-alat yang diperlukan.

6. Mencek pemahaman siswa terhadap masalah yang akan dipecahkan dan tugas-tugas siswa.

7. Memberi kesempatan pada siswa untuk melakukan penemuan.

8. Membantu siswa dengan informasi/data, jika diperlukan oleh siswa.

9. Memimpin analisis sendiri (self analysis) dengan pertanyaan yang mengarahkan dan mengidentifikasi proses.

10. Merangsang terjadinya interaksi antar siswa dengan siswa.

11. Memuji dan membesarkan siswa yang bergiat dalam proses penemuan.

12. Membantu siswa merumuskan prinsip-prinsip dan generalisasi atas penemuannya. 


\section{Pembelajaran Matematika Dengan Discovery Learning}

Discovery Learning merupakan suatu cara penyampaikan topiktopik matematika, sedemikian hingga proses belajar memungkinkan siswa menemukan sendiri pola-pola atau struktur-struktur matematika melalui serentetan pengalaman-pengalaman belajar yang lampau. Keteranganketerangan yang harus dipelajari itu tidak disajikan di dalam bentuk akhir, siswa diwajibkan melakukan aktivitas mental sebelum keterangan yang dipelajari itu dapat dipahami. Secara ekstrim, siswa benar-benar sebagai seorang "penemu" yang aktif menemukan berdasar pandangannya sendiri sedangkan gurunya hanya sebagai pengawas, bahkan tidak membimbing sama sekali. Fungsi guru disini bukan untuk menyelesaikan masalah bagi siswa-siswanya, melainkan siswa-siswanya mampu menyelesaikan sendiri masalah untuk dirinya.

Penemuan yang ekstrim ini tidak mungkin dilakukan yaitu guru hanya sebagai seorang pengawas yang pasif sedangkan siswanya harus belajar dengan caranya sendiri. Apa yang dihadapi siswa adalah benarbenar yang baru. Siswa-siswa tersebut memerlukan bimbingan, bahkan siswa-siswa itu memerlukan pertolongan guru setapak demi setapak. Siswa-siswa itu memerlukan waktu dan bantuan untuk mengembangkan kemampuannya memahami pengetahuan baru. Beberapa petunjuk atau instruksi perlu diberikan kepada siswa-siswanya apabila siswa-siswa itu tidak menunjukkan kemampuan. Memang benar bahwa siswa-siswa itu harus berusaha mengatasi kesulitan-kesulitan yang dihadapi tetapi pertolongan guru tetap diperlukan. Jadi metode yang digunakan adalah metode penemuan terbimbing. Dengan demikian mengajar menjadi suatu 
proses yang melibatkan secara optimum siswa-siswa untuk berpartisipasi di dalam proses belajar.

Diharapkan, jika siswa secara aktif terlibat di dalam menemukan suatu prinsip dasar sendiri, ia akan memahami konsep lebih baik, ingat lama dan akan mampu menggunakan ke dalam konteks yang lain. Selain dari itu, diharapkan bahwa siswa akan bergairah untuk mempelajari matematika dan ini akan membawa siswa ingin mengetahui lebih lanjut hubungan-hubungan yang lain.

\section{METODE PENELITIAN}

Penelitian ini adalah penelitian tindakan kelas (Classroom Action Research) dengan tahapan-tahapan pelaksanaan meliputi: perencanaan, pelaksanaan tindakan, pengamatan (observasi) dan refleksi secara berulang. Penelitian ini dilaksanakan di SMP Negeri 10 Bulukumba dengan subjek penelitian adalah seluruh siswa Kelas VIII A sebanyak 40 orang yang terdiri dari 19 laki-laki dan 21 perempuan.

\section{Faktor Yang Diselidiki}

Ada beberapa faktor yang diselidiki dalam penelitian ini. Faktorfaktor tersebut adalah sebagai berikut:

1. Faktor input, yang terdiri dari faktor siswa, materi pembelajaran, sumber belajar, prosedur evaluasi.

2. Faktor proses, pembelajaran dengan metode discovery learning.

3. Faktor output, hasil belajar siswa. 


\section{Prosedur Penelitian}

Prosedur penelitian ini dilaksanakan dalam dua siklus. Siklus pertama dilaksanakan sebanyak 4 kali pertemuan dan siklus kedua dilaksanakan sebanyak 5 kali pertemuan.

\section{Teknik Pengumpulan Data}

Sumber data pada penelitian tindakan kelas ini adalah dari siswa Kelas VIII A SMP Negeri 10 Bulukumba. Jenis data yang diperoleh berupa data kualitatif dan data kuantitatif yang terdiri dari:

1. Hasil observasi

2. Catatan harian

3. Skor hasil belajar

Cara Pengambilan Data

1. Data tentang keadaan selama kegiatan, diambil dengan menggunakan lembar observasi.

2. Data tentang refleksi diri dan perubahan yang terjadi di kelas diambil dari catatan harian.

3. Data tentang hasil belajar diambil dengan memberikan tes hasil belajar kepada siswa.

\section{Teknik Analisis Data}

Data yang terkumpul selanjutnya dianalisis dengan menggunakan analisis 'kuantitatif dan analisis kualitatif. Untuk analisis kuantitatif digunakan analisis deskriptif untuk mendeskripsikan karakteristik dari subjek penelitian. Adapun untuk keperluan analisis kualitatif akan digunakan teknik kategori tingkat penguasaan menurut Departemen Pendidikan dan Kebudayaan (1993:6) yaitu tingkat penguasaan siswa 85 
$\%-100 \%$ dikategorikan "sangat tinggi", $65 \%$ - 84 \% dikategorikan

"tinggi", $55 \%$ - 64\% dikategorikan "sedang", $35 \%$ - $54 \%$ dikategorikan "rendah" dan $0 \%$ - 34 \% dikategorikan "sangat rendah".

\section{Indikator Keberhasilan}

Indikator keberhasilan dalam penelitian ini adalah meningkatnya hasil belajar matematika siswa yang dapat dilihat dari skor rata-rata kelas.

\section{HASIL PENELITIAN DAN PEMBAHASAN}

Data tentang hasil tes akan dibahas secara kuantitatif dengan menggunakan statistika deskriptif, sedangkan data tentang pengamatan dalam proses belajar mengajar beserta tanggapan siswa akan dianalisis secara kualitatif.

\section{Analisis Kuantitatif}

Setelah selesai melaksanakan penelitian tindakan dengan menggunakan metode discovery learning yang terdiri dari dua siklus, maka hasil yang diperoleh sebagai berikut:

Tabel 1. Distribusi Frekuensi dan Proporsi Skor Hasil Belajar Matematika

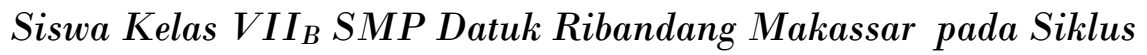
I dan Siklus II

\begin{tabular}{|c|c|c|c|c|l||}
\hline \multirow{2}{*}{ Skor } & \multirow{2}{*}{ Kategori } & \multicolumn{2}{|c|}{ Frekuensi } & \multicolumn{2}{c|}{ Proporsi } \\
\cline { 3 - 6 } & & Siklus I & Siklus II & Siklus I & Siklus II \\
\hline $0-34$ & Sangat & 5 & 2 & $12,5 \%$ & $5 \%$ \\
\hline
\end{tabular}




\begin{tabular}{|c|c|c|c|c|c|}
\hline & Rendah & & & & \\
\hline $35-54$ & Rendah & 11 & 2 & $27,5 \%$ & $5 \%$ \\
\hline $55-64$ & Sedang & 10 & 6 & $25 \%$ & $15 \%$ \\
\hline $65-84$ & Tinggi & 12 & 17 & $30 \%$ & $42,5 \%$ \\
\hline $85-100$ & $\begin{array}{l}\text { Sangat } \\
\text { Tinggi }\end{array}$ & 2 & 13 & $5 \%$ & $32,5 \%$ \\
\hline
\end{tabular}

Pada tabel di atas terlihat bahwa frekuensi dan proporsi siswa yang hasil belajarnya berada pada kategori sangat rendah, rendah dan sedang mangalami penurunan, sedangkan frekuensi dan proporsi siswa yang hasil belajarnya berada pada kategori tinggi dan sangat tinggi mengalami kenaikan. Ini berarti pembelajaran matematika dengan metode discovery learning dapat meningkatkan hasil belajar matematika siswa Kelas $\mathrm{VIII}_{\mathrm{A}}$ SMP Negeri 10 Bulukumba.

Dari skor rata-rata hasil belajar matematika siswa Kelas $\mathrm{VIII}_{\mathrm{A}}$ SMP Negeri 10 Bulukumba setelah dilaksanakan pembelajaran selama dua siklus dapat dilihat pada tebel sebagai berikut:

Tabel 2. Skor Rata-Rata Hasil Belajar Matematika untuk Siklus I dan Siklus II.

\begin{tabular}{|c|c|c|}
\hline Siklus & Skor Rata-Rata & Kategori \\
\hline I & 56,83 & Sedang \\
II & 73,98 & Tinggi \\
\hline
\end{tabular}


Pada tabel di atas, terlihat bahwa skor rata-rata hasil belajar siswa meningkat dari 56,83 pada siklus I menjadi 73,98 pada siklus II, demikian pula dengan kategorinya juga mengalami peningkatan dari kategori sedang menjadi kategori tinggi. Ini berarti bahwa pembelajaran dengan metode discovery learning dapat meningkatkan hasil belajar matematika

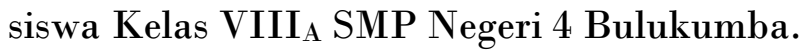

\section{Analisis Kualitatif}

Untuk mengetahui perubahan sikap dalam proses belajar mengajar dapat kita lihat pada hasil ovservasi yang dilakukan disetiap pertemuan. Disamping terjadinya peningkatan hasil belajar matematika siswa selama penelitian berlangsung dari siklus I hingga siklus II, tercatat pula sejumlah perubahan yang terjadi pada keaktifan siswa dalam mengikuti proses belajar - mengajar di kelas. Perubahan tersebut merupakan data kualitatif yang diperoleh dari lembar observasi pada setiap pertemuan yang dicatat oleh peneliti pada setiap siklus perubahan ini dapat dilihat dari hal-hal berikut:

1. Peningkatan hasil belajar siswa dapat dilihat dari meningkatnya persentase kehadiran siswa dari siklus I sebanyak 93,1\% siswa selama 4 kali pertemuan meningkat menjadi $98 \%$ siswa dengan 5 kali pertemuan pada siklus II. Hal ini menandakan bahwa motivasi siswa untuk mengikuti pembelajaran dengan pendekatan kontekstual semakin meningkat.

2. Perhatian siswa terhadap proses belajar mengajar mengalami peningkatan, hal ini ditandai dengan semakin banyaknya siswa yang serius dalam memperhatikan materi. Hal ini dapat dilihat dari 
persentase pada siklus I sebanyak 84,4 \% meningkat menjadi 88,82\% pada siklus II, hal ini menandakan bahwa siswa benar-benar serius dalam memperhatikan penjelasan materi yang diberikan oleh guru.

3. Keaktifan siswa dalam hal tampil di depan untuk menyelesaikan soalsoal di papan tulis juga mengalami peningkatan. Hal ini terlihat dari sejumlah siswa yang berani mengajukan diri untuk tampil ke depan dalam mengerjakan soal-soal. Pada awal pertemuan pada umumnya siswa ragu-ragu dan malu untuk tampil ke depan menyelesaikan soal di papan tulis. Mereka merasa takut jika soal yang dikerjakan salah atau kurang tepat, maka akan menjadi bahan tertawaan temantemannya. Akan tetapi dengan dorongan dan nasehat-nasehat yang bisa membangkitkan semangatnya, akhirnya setelah beberapa kali pertemuan sudah banyak siswa yang berlomba-lomba untuk tampil ke depan. Ini terbukti pada siklus I sebanyak $16,9 \%$ meningkat menjadi $49 \%$ pada siklus II.

4. Siswa yang aktif dalam menjawab pertanyaan lisan guru atau rekannya pada proses belajar-mengajar berlangsung mengalami kemajuan. Awal pertemuan jika ada pertanyaan yang diberikan, mereka pada umumnya hanya diam. Tetapi setelah beberapa kali pertemuan akhirnya sudah ada keberanian untuk menjawab secara lisan pertanyaan yang diberikan. Hal ini ditandai dengan adanya peningkatan jumlah siswa yang menjawab pertanyaan lisan guru atau rekannya dari siklus I tercatat $15 \%$ meningkat menjadi $23 \%$.

5. Siswa yang kurang aktif dalam kelompoknya mengalami penurunan. Hal ini ditunjukkan dengan berkurangnya siswa yang tidak mau 
terlibat atau tidak mau bekerja sama dengan temannya menyelesaikan tugas kelompok yang diberikan. Ini terbukti pada siklus I sebanyak $20 \%$ menurun menjadi $13 \%$.

6. Keaktifan siswa dalam mempersentasekan hasil diskusinya sebagai perwakilan dari kelompoknya mengalami peningkatan. Terlihat dengan semakin banyaknya siswa yang memiliki semangat keberanian untuk tampil ke depan dalam mempersentasekan hasil kelompoknya. Dari $23,1 \%$ siswa yang mempersentasekan hasil diskusinya sebagai perwakilan dari kelompoknya pada Siklus I meningkat menjadi 48,5 \% pada Siklus II.

7. Siswa yang menjawab pertanyaan atau tanggapan kelompok lain pada saat persentae kelompoknya mengalami peningkatan. Ini menunjukkan bahwa adanya rasa tanggung jawab yang dimiliki oleh siswa dalam mempertahankan hasil kerja kelompoknya. Tercatat pada siklus I sebanyak 8,13\% meningkat menjadi 18,13\%.

8. Perhatian dan kesungguhan siswa dalam proses belajar-mengajar juga dapat dilihat pada kesadaran siswa dalam mengerjakan tugas atau pekerjaan rumah, serta mengumpulkan tepat waktu. Tercatat pada siklus I sebanyak 57,5 \% meningkat menjadi 89,5\%.

\section{SIMPULAN}

Berdasarkan analisis data dan pembahasan maka dapat ditarik kesimpulan bahwa hasil belajar matematika Siswa Kelas $\mathrm{VIII}_{\mathrm{A}} \mathrm{SMP}$ Negeri 10 Bulukumba mengalami peningkatan setelah diadakan 
pembelajaran dengan metode discovery learning dengan indikasi sebagai berikut:

1. Skor rata-rata belajar matematika Siswa Kelas $\mathrm{VIII}_{\mathrm{A}} \mathrm{SMP}$ Negeri 10 Bulukumba setelah diberi tindakan pada Siklus I adalah 56,83 dari skor tertinggi yang mungkin dicapai yaitu 100 atau berada pada kategori sedang.

2. Skor rata-rata hasil belajar matematika Siswa Kelas $\mathrm{VIII}_{A} \mathrm{SMP}$ Negeri 10 Bulukumba setelah diberikan tindakan pada Siklus II adalah 73,98 dar skor tertinggi yang mungkin dicapai yaitu 100 atau berada dalam kategori tinggi.

3. Penerapan pembelajaran dengan metode discovery learning dapat meningkatkan hasil belajar Siswa Kelas VIII $_{A}$ SMP Negeri 10 Bulukumba yang indikatornya berupa peningkatan skor rata-rata hasil belajar matematika siswa dari kategori sedang pada Siklus I sebesar 56,83 menjadi 73,98 pada Siklus II yang berada pada kategori tinggi.

4. Terjadinya peningkatan keaktifan dan partisipasi siswa dalam proses belajar mengajar. Hal ini terlihat dari adanya peningkatan frekuensi kehadiran siswa, perhatian dan kesungguhan dalam mengikuti proses belajar mengajar baik dalam hal bertanya atau memberi tanggapan baik pada saat persentase kelompok maupun pada saat penjelasan materi, menjawab pertanyaan lisan guru atau rekannya, mengerjakan tugas sekolah dan tugas di rumah, serta menyelesaikan soal di papan tulis. 


\section{SARAN DAN REKOMENDASI}

Mengacu kepada pembahasan hasil penelitian dan kesimpulan di atas maka dapat disarankan kepada:

1. Para peneliti untuk dapat melakukan penelitian yang lebih luas dan mendalam, dengan mengambil sampel penelitian yang lebih besar sehingga kesimpulannya bisa lebih representatif.

2. Guru diharapkan dapat menerapkan metode pembelajaran discovery learning sebagai salah satu pembelajaran inovatif yang dapat meningkatkan hasil pembelajaran matematika.

3. Siswa diharapkan mampu mengembangkan kreatifitas dan keaktifan dalam proses belajar matematika melalui penerapan metode discovery learning.

\section{DAFTAR PUSTAKA}

Depdikbud. 1993. Evaluasi dan Penilaian. Jakarta: Proyek Peningkatan Mutu Guru Dirjen DIKNASMEN.

Hudoyo, Herman. 1980. Teori Dasar Belajar-Mengajar Matematika. Jakarta: Proyek Pengembangan Pendidikan Guru (P3G) Departemen Pendidikan dan Kebudayaan. - 1990. Strategi Mengajar Belajar Matematika. Malang:

IKIP Malang. . 2001. Pengembangan Kurikulum dan Pembelajaran

Matematika. Malang: Universitas Negeri Malang. - 2003. Pengembangan Kurikulum dan Pembelajaran Matematika. Malang: JICA- IMSTEP.

Jusnidar. 2003. Meningkatkan Hasil belajar Matematika Melalui Pemberian Tugas Pekerjaan Rumah Disertai Umpan Balik Siswa Kelas IV SDN 303 Tondo Tangnga. Skripsi FMIPA Universitas Negeri Makassar: Tidak diterbitkan.

Mardiana. 2002. Meningkatkan Kemampuan Menyelesaikan Soal-soal Matematika Pada Siswa Kelas II SLTP Negeri 2 Sungguminasa 
Melalui Pemberian Kuis dengan Umpan Balik. Skripsi FMIPA Universitas Negeri Makassar: Tidak diterbitkan

Masnaini. 2003. Meningkatkan Hasil belajar Matematika Melalui Pemberian Kuis Dengan mencongak di Awal Setiap Pertemuan Pada Siswa Kelas V SDN 353 Patalabunga. Skripsi FMIPA Universitas Negeri Makassar: Tidak diterbitkan.

Nurhasana. 2003. Mengefektifkan Pembelajaran Matematika Melalui Gaya Mengajar Auditorial Pada Murid Kelas V SD Negeri Bonepute. Skripsi FMIPA Universitas Negeri Makassar: Tidak diterbitkan.

Retno Prima, Dra. 2000. Pengajaran Berpusat Kepada Siswa dan

Pendekatan Konstruktivis Dalam Pengajaran. Surabaya.

Universitas Negeri Surabaya.

Sahabuddin H, 1999. Mengajar dan Belajar. Makassar: UNM Makassar.

Soedjana. 1980. Strategi Belajar Mengajar Matematika. Jakarta: Karunika Jakarta: Universitas Terbuka.

Sudjatmiko, Ponco. 2004. Matematika Kreatif Konsep dan Penerapannya. Solo: PT. Tiga Serangkai Pustaka Mandiri.

Suherman, Erman., Turmudi., Suryadi, Didi., Herman, Tatang., Suhendra., Prabawanto, Sufyani., Nurjanah, Rohayati, Ade. 2003. Strategi Pembelajaran Matematika Kontemporer. Bandung: Penerbit Universitas Pendidikan Indonesia.

Suryosubroto, B. 1997. Proses Belajar Mengajar di Sekolah. Jakarta: Rineka Cipta.

Tim Pelatih Proyek PGSM. 1999. Penelitian Tindakan Kelas (Classroom Action Research). Jakarta: Departemen Pendidikan dan Kebudayaan Direktorat Jenderal Pendidikan Tinggi Proyek Pengembangan Guru Sekolah Menengah. 